\title{
A Comprehensive Investigation of the Mineral Composition of Brazilian Bee Pollen: Geographic and Seasonal Variations and Contribution to Human Diet
}

\author{
Marcelo A. Morgano, ${ }^{*, a}$ Márcia C. Teixeira Martins, ${ }^{b}$ Luana C. Rabonato, ${ }^{a}$ \\ Raquel F. Milani, ${ }^{a}$ Katumi Yotsuyanagi ${ }^{a}$ and Delia B. Rodriguez-Amaya ${ }^{c}$ \\ ${ }^{a}$ Centro de Ciência e Qualidade de Alimentos, Instituto de Tecnologia de Alimentos (ITAL), \\ Av. Brasil, 2880, 13070-178 Campinas-SP, Brazil \\ ${ }^{b}$ Centro Universitário Adventista de São Paulo, Estrada de Itapecerica, 5859, \\ 05858-001 São Paulo-SP, Brazil \\ ${ }^{c}$ Faculdade de Engenharia de Alimentos, Universidade Estadual de Campinas, \\ CP 6121, 13083-862 Campinas-SP, Brazil
}

\begin{abstract}
A composição de minerais foi investigada em 154 amostras de pólen apícola, provenientes de diferentes regiões do Brasil. A técnica de ICP OES foi utilizada para determinar $\mathrm{Ca}, \mathrm{Cu}, \mathrm{Fe}, \mathrm{K}$, $\mathrm{Mg}, \mathrm{Mn}, \mathrm{Na}, \mathrm{P}$, Se e Zn, após mineralização em sistema de microondas. Utilizando parâmetros instrumentais otimizados conseguiu-se boa exatidão e precisão na determinação simultânea dos minerais. Em geral, as amostras dos estados do Nordeste apresentaram teores de minerais mais elevados e produção constante durante o ano. Os minerais $\mathrm{Mn}, \mathrm{Se}, \mathrm{Cu}, \mathrm{Zn}$, Fe são os que poderiam ter maior contribuição na dieta, podendo atingir 70,37, 27, 17 e 17\%, respectivamente, da ingestão dietética diária recomendada no Brasil. A análise de componentes principais mostrou que $\mathrm{Ca}, \mathrm{Cu}$, $\mathrm{Fe}, \mathrm{K}, \mathrm{Mg}, \mathrm{Mn}, \mathrm{Na}, \mathrm{P}$ e Zn podem ser usados na classificação do pólen nacional em função da origem geográfica. Os teores dos minerais variaram amplamente ao longo do ano.
\end{abstract}

The mineral composition of bee pollen was investigated in 154 samples from different Brazilian regions. $\mathrm{Ca}, \mathrm{Cu}, \mathrm{Fe}, \mathrm{K}, \mathrm{Mg}, \mathrm{Mn}, \mathrm{Na}, \mathrm{P}$, Se and $\mathrm{Zn}$ were determined by ICP OES after microwave mineralization. Employing optimized instrumental parameters, the method was shown to have a good precision and accuracy for the simultaneous determination of minerals. Overall, samples from the Northeastern states presented significantly higher amounts of minerals and showed constant production throughout the year. Manganese, $\mathrm{Se}, \mathrm{Cu}, \mathrm{Zn}$ and $\mathrm{Fe}$ were the elements that showed the greatest possible contributions to the diet, contributing with 70,37, 27, 17 and 17\%, respectively, of the Brazilian recommended daily intake. Principal component analysis (PCA) was applied to study geographic effects. The elements $\mathrm{Ca}, \mathrm{Cu}, \mathrm{Fe}, \mathrm{K}, \mathrm{Mg}, \mathrm{Mn}, \mathrm{Na}, \mathrm{P}$ and $\mathrm{Zn}$ were important in explaining the classification of pollen according to their geographical origin. The mineral levels varied widely during the year.

Keywords: bee pollen, minerals, ICP OES

\section{Introduction}

Bee pollen, often referred to as a natural supplement, is one of the emerging bee products valued by its high content of nutrients and other health-promoting constituents. Brazilian honey has become an important product for domestic consumption and export, the latter having increased by $12 \%$ of its value in 2010 . The major importing country is the United States, followed by Germany, the

*e-mail: morgano@ital.sp.gov.br
United Kingdom, Canada, Austria, France and Spain. ${ }^{1}$ Official data for the pollen is not available, but it is known that the current production is not sufficient to meet the national demand. Beekeeping has gradually increased in Brazil favored by plant diversification, vast land area and favorable climatic conditions (tropical climate). ${ }^{2}$

Bee pollen has 13 to $55 \%$ carbohydrates, 10 to $40 \%$ proteins, 1 to $20 \%$ lipids, 3 to $8 \%$ water, minerals

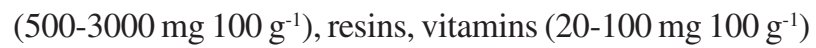

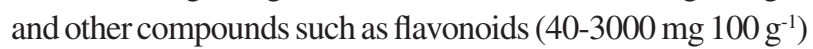
and antibiotic substances. ${ }^{3-7}$ Brazilian studies on the 
macronutrient and micronutrient composition of bee pollen, however, are still limited. ${ }^{8,9}$

The chemical composition of bee pollen is known to vary with the methods of extraction and storage, the floral origin (plant species), including age and nutritional status of the plant, and environmental conditions. ${ }^{10}$ According to O'Rourke and Buchmann, ${ }^{11}$ pollen composition may vary in different locations, between seasons and years. Funari et al. ${ }^{8}$ found variations in mineral composition of Brazilian bee pollen collected in one apiary from Botucatu during a period of four months. Knowledge of the nutritional value and quality of bee pollen produced in different regions may contribute to the choice of the place to install apiaries. ${ }^{12,13}$

Some mineral elements have already been quantified in bee pollen samples from several countries: potassium (K), phosphorus $(\mathrm{P})$, magnesium $(\mathrm{Mg})$, calcium $(\mathrm{Ca}), \operatorname{sodium}(\mathrm{Na})$, sulfur $(\mathrm{S})$, iron $(\mathrm{Fe})$, copper $(\mathrm{Cu})$, manganese $(\mathrm{Mn})$, zinc $(\mathrm{Zn})$, chromium $(\mathrm{Cr})$, nickel $(\mathrm{Ni})$ and selenium $(\mathrm{Se}){ }^{6,8,14-}$ ${ }_{19}$ The number of samples analyzed, however, is limited, varying from one ${ }^{19}$ to fifty ${ }^{16}$ per study. Two of them are Brazilian studies, involving 24 samples collected in only one sampling site from the state of São Paulo ${ }^{8}$ and 36 samples from Southern Brazil. ${ }^{9}$

The main analytical techniques used to determine mineral elements in bee pollen samples are atomic absorption spectrometry (AAS), ${ }^{7,17,18,20}$ electrothermal atomization atomic absorption spectrometry (ET-AAS), ${ }^{21}$ inductively coupled plasma optical emission spectrometry (ICP OES), ${ }^{6,16}$ and X-ray fluorescence spectrometry (XRF). ${ }^{15}$

Baldi-Coronel et al. ${ }^{17}$ determined $\mathrm{K}, \mathrm{Ca}, \mathrm{Mg}, \mathrm{Na}$, $\mathrm{Fe}, \mathrm{Zn}, \mathrm{Mn}$ and $\mathrm{Cu}$ by AAS in bee pollen ash obtained by calcination of samples at $550{ }^{\circ} \mathrm{C}$. Szczesna found in decreasing order the minerals $\mathrm{K}>\mathrm{Mg}>\mathrm{Na}>\mathrm{Ca}>\mathrm{Fe}>$ $\mathrm{Mn}>\mathrm{Zn}>\mathrm{Cu}$ in bee pollen samples collected in Poland, South Korea and China, after sample mineralization in acid medium using an open microwave-assisted system and quantification by AAS. ${ }^{18}$ Somerville and $\mathrm{Nicol}^{16}$ used ICP OES to quantify $\mathrm{K}, \mathrm{P}, \mathrm{S}, \mathrm{Ca}, \mathrm{Mg}, \mathrm{Na}, \mathrm{Fe}, \mathrm{Zn}$, $\mathrm{Mn}$ and $\mathrm{Cu}$ in bee pollen from New South Wales after sample digestion in closed microwave-assisted system. Serra-Bonvehí and Escolà-Jordà ${ }^{6}$ determined $\mathrm{Fe}, \mathrm{Ca}, \mathrm{Zn}, \mathrm{K}$, $\mathrm{Na}, \mathrm{Cu}, \mathrm{Mg}, \mathrm{P}$ and $\mathrm{Mn}$ in Spanish bee pollen, also using ICP OES after calcination. Comparing dry and wet digestion, Kump et al. ${ }^{15}$ obtained the best results by ashing the sample in the presence of diluted $\mathrm{H}_{2} \mathrm{SO}_{4}$ (1:4). These authors used $\mathrm{XRF}$ to determine $\mathrm{K}, \mathrm{Ca}, \mathrm{Mn}, \mathrm{Fe}, \mathrm{Ni}, \mathrm{Cu}, \mathrm{Zn}, \mathrm{Rb}$ and $\mathrm{Pb}$ in bee pollen samples from Slovenia.

In a previous study, the occurrence of inorganic contaminants in bee pollen from Southeastern Brazil was reported. ${ }^{22}$ The purpose of the present paper was to analyze bee pollen samples from Brazilian producing regions for the mineral elements $\mathrm{Ca}, \mathrm{Cu}, \mathrm{Fe}, \mathrm{K}, \mathrm{Mg}, \mathrm{Mn}, \mathrm{Na}, \mathrm{P}, \mathrm{Se}$ and $\mathrm{Zn}$. To reach this goal, a method using sample digestion in closed microwave-assisted system and quantification by ICP OES was optimized. While food safety was the concern of the previous paper, the current work deals with the nutritional value, geographic and seasonal variations of this increasingly important food product.

\section{Experimental}

\section{Sampling}

A total of 154 Brazilian dehydrated bee pollen samples ready for commercialization (dry, clean and packaged products) were directly purchased from apiculture producers of Southern, Southeastern, Central, Northeastern and Midwestern regions (Table 1) during a year. Samples (weighing 200 to $300 \mathrm{~g}$ ) were transported to Campinas, SP, mostly in plastic bags, some in glass containers, simulating commercialization practices.

Table 1. Localization of bee pollen sample collection regions

\begin{tabular}{|c|c|c|}
\hline Region & State & City (number of sampling sites) \\
\hline \multirow{3}{*}{ Southern } & RS & Cruz Alta (9) \\
\hline & $\mathrm{SC}$ & Campos Novos (17), Porto União (13) \\
\hline & PR & Ilha Grande (3), Lapa (7) \\
\hline \multirow{3}{*}{ Southeastern } & SP & $\begin{array}{l}\text { São José dos Campos (9), Santa Branca (7), } \\
\text { Holambra (3), Guaratinguetá (4) }\end{array}$ \\
\hline & MG & $\begin{array}{l}\text { Marmelópolis (4), Belo Oriente (2), Entre Rios } \\
\text { de Minas (4) }\end{array}$ \\
\hline & ES & Pedra Azul (10) \\
\hline Central & DF & Federal Distict (3) \\
\hline \multirow{4}{*}{ Northeastern } & BA & Canavieiras (24), Ilhéus (10), Norte Bahia (3) \\
\hline & SE & Neópolis (13), Aracaju (1), Salgado (4) \\
\hline & PI & Teresina (1) \\
\hline & $\mathrm{CE}$ & Trairí (1) \\
\hline Midwestern & MT & Cáceres (2) \\
\hline
\end{tabular}

RS, Rio Grande do Sul; SC, Santa Catarina; PR, Paraná; SP, São Paulo; MG, Minas Gerais; ES, Espírito Santo; MT, Mato Grosso; BA, Bahia; CE, Ceará; PI, Piauí; SE, Sergipe; DF, Federal District.

\section{Sample preparation}

In the laboratory, the samples were packed under vacuum in polyamide and polyethylene bags, to avoid absorption of moisture and oxygen, and stored in a freezer at $-16{ }^{\circ} \mathrm{C}$ until analyses were carried out (maximum of 3 months). On the day of analysis, samples were quartered in a stainless steel quartering equipment and ground in a refrigerated mill with 
tungsten helix (M20, IKA Labortechnik, Staufen, Baden, $\mathrm{Ge})$. The samples were then sieved using a 30-mesh $(600 \mu \mathrm{m})$ sieve to standardize pollen particles size.

\section{Analytical determination}

Digestion was performed in a closed microwave acid digestion unit with 41 digestion bottles (Microwave Digestion System Start D, Milestone, Sorisole, Italy), using nitric acid 65\% (m/m) (Merck, Farmstadt, Germany) and hydrogen peroxide 30\% (v/v) (Merck, Darmstad, Germany) as oxidizing agents. A sample of 0.65-0.70 $\mathrm{g}$ was weighed in the digestion bottle and $10 \mathrm{~mL}$ of concentrated nitric acid were added, followed by $3 \mathrm{~mL}$ of $30 \%$ hydrogen peroxide. Digestion was performed in two phases, with 30 min of cooling after each phase. Power was maintained at $1000 \mathrm{~W}$ and external temperature of the reaction vessel was at $110^{\circ} \mathrm{C}$. For phase 1 three stages of 20,20 and 30 min were undertaken, the internal temperature of the reaction vessel being kept at 140,160 and $180^{\circ} \mathrm{C}$, respectively. Phase 2 had two stages of 20 and 30 min with the internal temperature of the reaction vessel at 180 and $200{ }^{\circ} \mathrm{C}$, respectively. Once digestion was completed, the bottle's content was transferred to a $25 \mathrm{~mL}$ volumetric flask, the volume being completed with a $5 \% \mathrm{HCl}$ solution (v/v). ${ }^{22}$

Quantification of mineral elements was performed by ICP OES, using a Varian Vista MPX model (Mulgrave Victoria, Australia), with axial vision, equipped with a radio frequency (RF) source of $40 \mathrm{MHz}$, a Charge Coupled Device (CCD-type) simultaneous multi-element solid state detector, a peristaltic pump, a spraying chamber and a sea spray nebulizer. The system was controlled by ICP Expert software and $99.996 \%$ liquid argon was used as plasma gas (Air Liquid, SP, Brazil). Operating conditions of the ICP OES equipment were: forward power, $1000 \mathrm{~W}$; nebulizer Ar flow rate, $0.9 \mathrm{~L} \mathrm{~min}^{-1}$; auxiliary argon flow, $1.5 \mathrm{~L} \mathrm{~min}^{-1}$; cooling Ar flow rate, $15 \mathrm{~L} \mathrm{~min}^{-1}$; background correction, 2 points; integration and reading time, $10 \mathrm{~s}$; replicate number, 3 and axial torch configuration. The analytical line wavelengths were: $\mathrm{Ca}, 317.933 \mathrm{~nm}$; $\mathrm{Cu}, 324.754 \mathrm{~nm}$; Fe, $259.940 \mathrm{~nm}$; K, $766.491 \mathrm{~nm}$; Mg, $280.270 \mathrm{~nm}$; Mn, $257.610 \mathrm{~nm}$; Na, $589.592 \mathrm{~nm}$; P, $213.618 \mathrm{~nm}$; Se, $196.026 \mathrm{~nm} ; \mathrm{Zn}, 206.200 \mathrm{~nm}$.

Stock solutions at $10,000 \mathrm{mg} \mathrm{L}^{-1}$ for $\mathrm{Ca}, \mathrm{K}, \mathrm{Mg}, \mathrm{Na}$ (Titrisol - Merck) and P (Qhemis High Purity) and at 1,000 $\mathrm{mg} \mathrm{L}^{-1}$ for $\mathrm{Cu}, \mathrm{Fe}, \mathrm{Mn}, \mathrm{Zn}$ (Merck) and Se (Qhemis High Purity) were used for preparing the standard solutions in $5 \% \mathrm{HCl} \mathrm{v} / \mathrm{v}$. The concentration ranges of the standard solutions were: 0.005 to $0.5 \mathrm{mg} \mathrm{L}^{-1}$ of $\mathrm{Cu}$ and $\mathrm{Se}, 0.05$ to $2.5 \mathrm{mg} \mathrm{L}^{-1}$ of Fe, Mn and $\mathrm{Zn}, 0.5$ to $15.0 \mathrm{mg} \mathrm{L}^{-1}$ of $\mathrm{Na}, 5.0$ to $75.0 \mathrm{mg} \mathrm{L}^{-1}$ of Ca, P and $\mathrm{Mg}$ and 25.0 to $150.0 \mathrm{mg} \mathrm{L}^{-1}$ of $\mathrm{K}$.
Assurance of quality in analytical procedure

Method accuracy was evaluated by recovery tests conducted at two levels, covering the concentration ranges in the samples. The limit of detection (LOD) and limit of quantification (LOQ) values were calculated as suggested by Mermet and Poussel: ${ }^{23}$ LOD $=(3 \mathrm{RSD}$ BEC $) / 100$ and $\mathrm{LOQ}=5 \mathrm{LOD}$, where $\mathrm{RSD}$ is the relative standard deviation and $\mathrm{BEC}$ is the background equivalent concentration, determined experimentally $(n=8)$. Method precision was evaluated by the coefficient of variation of 8 repetitions.

Because of the unavailability of a certified reference material for bee pollen, a certified reference material, NIST 1566a (oyster tissue), was used only to validate analytical control of the laboratory under existing working conditions. This material has certified values for $\mathrm{Ca}, \mathrm{Cu}$, $\mathrm{Fe}, \mathrm{K}, \mathrm{Mg}, \mathrm{Mn}, \mathrm{Na}$, Se and Zn. Results were assessed by the relative error.

\section{Statistical analysis}

In order to verify if the means obtained for mineral elements of dehydrated bee pollen samples from different states could be considered statistically different at a significance level of $\mathrm{p}<0.05$, Tukey's multiple comparison test was applied (employing the approach method with different repetition numbers per state) using the software Statistica for Windows 5.5 (StatSoft Inc., Tulsa, USA).

Hierarchical cluster analysis (HCA) and principal component analysis (PCA)

Using mean values, a data matrix $(154 \times 10)$ was built, in which samples were put in lines and the concentration of minerals were put in columns (variables). Data were preprocessed and then submitted to HCA and PCA, using Statistica program version 5.0. The HCA statistical analysis was performed with the purpose of verifying similarities between samples from different states, clustering samples by similarity from the Euclidean distance calculated. HCA results were presented as a bi-dimensional graph called dendogram. PCA analysis was used as a chemometric tool to verify which mineral elements were important for the separation of the groups formed.

\section{Estimation of microelement daily intake}

Contribution of mineral elements in bee pollen to dietary intake was estimated according to the recommended daily intake (RDI) values established by Brazilian regulation for adults, ${ }^{24}$ based on the recommended nutrient intakes 
(RNI) for $\mathrm{Ca}, \mathrm{Fe}, \mathrm{Mg}, \mathrm{Zn}$ and $\mathrm{Se}^{25}$ and the dietary reference intakes (DRI) values for $\mathrm{Cu}, \mathrm{Mn}^{26}$ and $\mathrm{P}^{27}$ Potassium DRI level was adopted from the Institute of Medicine, ${ }^{28}$ since the Brazilian regulation does not establish a recommendation for this mineral. To estimate the microelement daily intake, the portion size for bee pollen recommended by Lengler was used, which is $25 \mathrm{~g}$ (approximately three tablespoons) for adults. ${ }^{29}$

\section{Results and Discussion}

\section{Method performance}

Sample digestion using a microwave-assisted closed system allowed quantification of the mineral elements $\mathrm{Ca}, \mathrm{Cu}, \mathrm{Fe}, \mathrm{K}, \mathrm{Mg}, \mathrm{Mn}, \mathrm{Na}, \mathrm{P}, \mathrm{Se}$ and $\mathrm{Zn}$ in a single sample preparation. The residual carbon content was $0.15 \mathrm{~g} \mathrm{~kg}^{-1}$, indicating low level of organic matter after sample digestion. The time spent to digest the samples was approximately $180 \mathrm{~min}$.

The method exhibited good performance, confirmed by $r$ values close to 1, LOD and LOQ with appropriate sensitivity to determine the minerals and satisfactory $\mathrm{CV}$ at the detection levels achieved (Table 2). The working standards solutions for the calibration and reagent blanks used for the estimation of the linearity ranges and limits of detection and quantification were subjected to the digestion procedure. Recovery results in polen matrix were within the range of 70 to $106 \%$, mostly close to $100 \%$, indicating adequacy of the analytical method.

The results obtained in the laboratory analytical control evaluation, using the oyster tissue NIST 1566a certified reference material, under the same preparation conditions for bee pollen samples, showed adequacy of the method. For all elements, relative error was below $8 \%$ (Table 2).

\section{Composition of mineral elements in Brazilian bee pollen} sample

Mean contents, standard deviations and concentration ranges obtained for the minerals in the 154 dehydrated bee pollen samples from 11 states and the Federal District are shown in Table 3. In general, wide within-state and between-state concentration ranges were obtained, especially for $\mathrm{Se}, \mathrm{Na}$ and $\mathrm{Cu}$, which had standard deviations higher than the means.

A perusal of the between-state variation shows higher Ca levels in PI, CE, SE, BA and MT samples, while those of SE, CE and PI had higher amounts of P. There was no significant variation of $\mathrm{Cu}$ and $\mathrm{Mn}$ among the states. Samples from MG and DF had higher levels of Fe, than those of the other states, but the differences did not reach significant levels. Samples from SE, DF, PI, CE, BA and MT had greater amounts of $\mathrm{K}$ and $\mathrm{Mg}$, but for the latter, PR also had higher

Table 2. Performance characteristics of the method for determining bee pollen mineral elements

\begin{tabular}{|c|c|c|c|c|c|c|c|c|}
\hline \multirow{2}{*}{ Element } & \multirow{2}{*}{$\mathrm{r}$} & \multirow{2}{*}{$\mathrm{LOD} /\left(\mathrm{mg} \mathrm{L}^{-1}\right)$} & \multirow{2}{*}{$\mathrm{LOQ} /\left(\mathrm{mg} \mathrm{L}^{-1}\right)$} & \multirow{2}{*}{$\mathrm{CV} / \%$} & \multicolumn{2}{|c|}{ Oyster tissue / $\left(\mathrm{mg} \mathrm{kg}^{-1}\right)$} & \multirow{2}{*}{$\begin{array}{c}\text { Fortification } \\
\text { level / }\left(\mathrm{mg} \mathrm{L}^{-1}\right)\end{array}$} & \multirow{2}{*}{ Recovery / \% } \\
\hline & & & & & Certified Value & Measured Value* & & \\
\hline \multirow[t]{2}{*}{$\mathrm{Ca}$} & 0.9999 & 0.001 & 0.003 & 5.6 & $793 \pm 15$ & $838 \pm 20$ & 20.05 & 106 \\
\hline & & & & & & & 31.00 & 96 \\
\hline \multirow[t]{2}{*}{$\mathrm{Cu}$} & 1.0000 & 0.003 & 0.01 & 1.7 & $67.7 \pm 1.2$ & $71.6 \pm 1.6$ & 0.10 & 85 \\
\hline & & & & & & & 0.15 & 87 \\
\hline \multirow[t]{2}{*}{$\mathrm{Fe}$} & 0.9998 & 0.001 & 0.03 & 1.7 & $212.9 \pm 1.3$ & $205.8 \pm 6.8$ & 0.10 & 94 \\
\hline & & & & & & & 1.00 & 98 \\
\hline \multirow[t]{2}{*}{ K } & 0.9952 & 0.006 & 0.03 & 2.7 & $6531 \pm 156$ & $6520 \pm 90$ & 20.05 & 86 \\
\hline & & & & & & & 36.00 & 97 \\
\hline \multirow[t]{2}{*}{$\mathrm{Mg}$} & 0.9954 & 0.0001 & 0.001 & 1.5 & $1100 \pm 30$ & $1085 \pm 23$ & 30.00 & 71 \\
\hline & & & & & & & 50.00 & 80 \\
\hline \multirow[t]{2}{*}{$\mathrm{Mn}$} & 0.9998 & 0.0001 & 0.0004 & 7.0 & $18.7 \pm 0.1$ & $18.5 \pm 0.2$ & 0.80 & 80 \\
\hline & & & & & & & 1.00 & 73 \\
\hline \multirow[t]{2}{*}{$\mathrm{Na}$} & 0.9992 & 0.004 & 0.02 & 3.5 & $3482 \pm 140$ & $3297 \pm 530$ & 2.00 & 90 \\
\hline & & & & & & & 4.00 & 85 \\
\hline \multirow[t]{2}{*}{$\mathrm{P}$} & 0.9998 & 0.009 & 0.04 & 2.5 & - & - & 25.00 & 94 \\
\hline & & & & & & & 40.00 & 94 \\
\hline \multirow[t]{2}{*}{$\mathrm{Se}$} & 0.9995 & 0.01 & 0.07 & 13.5 & $1.88 \pm 0.32$ & $2.06 \pm 0.15$ & 0.01 & 70 \\
\hline & & & & & & & 0.10 & 102 \\
\hline \multirow[t]{2}{*}{$\mathrm{Zn}$} & 0.9999 & 0.004 & 0.02 & 2.3 & $1420 \pm 17$ & $1424 \pm 46$ & 0.80 & 103 \\
\hline & & & & & & & 1.00 & 92 \\
\hline
\end{tabular}

$\mathrm{r}$, coefficient of correlation; LOD, limit of detection; LOQ, limit of quantification; CV, coefficient of variation; $* \mathrm{n}=3$. 


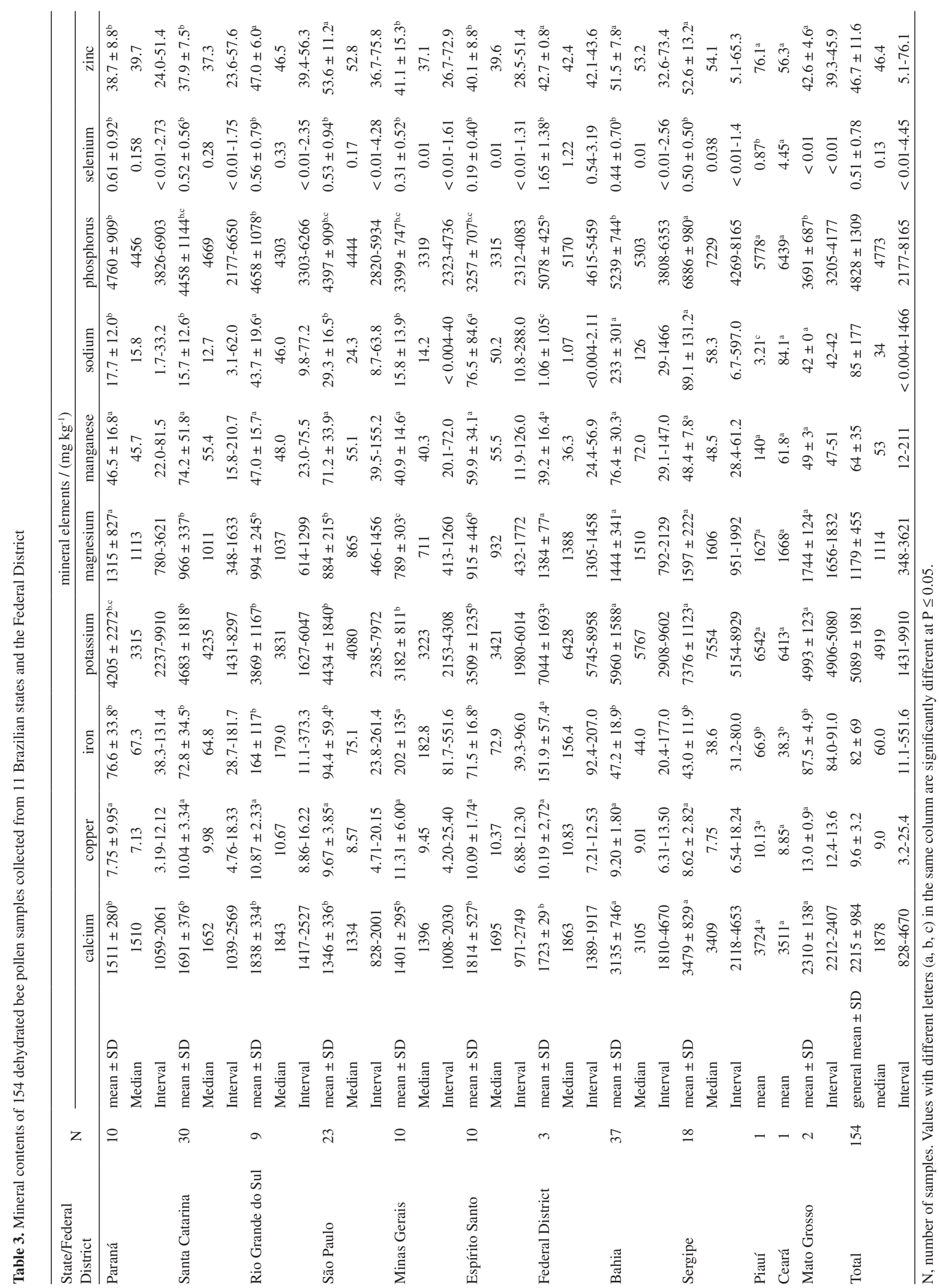


levels. Samples from BA, SE, CE, RS and MT had higher amounts of $\mathrm{Na}$. The $\mathrm{CE}$ samples presented the highest level of Se (4.45 mg kg-1), comparable to a single sample from Santa Branca, SP (4.28 $\mathrm{mg} \mathrm{kg}^{-1}$ ). Higher levels of $\mathrm{Zn}$ were found in samples from PI, CE, SP, SE, BA, RS, DF and MT.

Overall, greater amounts of minerals were found in bee pollen samples from Northeastern (CE, SE, PI, BA), Midwestern (DF) and Central Brazil (MT). One state from Southeastern Brazil (MG) presented the highest average level of Fe. Nevertheless, it should be emphasized that the interpretation of these data is limited by the small number of samples collected in PI, CE, MT and DF, where bee pollen production was low during the period of the present study.

The predominant minerals of Brazilian bee pollen were $\mathrm{K}, \mathrm{P}, \mathrm{Ca}$ and $\mathrm{Mg}$ comprising 37, 36, 16 and 9\%, respectively of the mean composition. Present in lower proportions were $\mathrm{Na}(0.63 \%), \mathrm{Fe}(0.60 \%), \mathrm{Mn}(0.47 \%), \mathrm{Zn}(0.34 \%)$, $\mathrm{Cu}(0.07 \%)$ and $\mathrm{Se}(0.004 \%)$.

The wide range of $\mathrm{K}$ levels found in the present study (1431-9910 $\mathrm{mg} \mathrm{kg}^{-1}$ ), covered the ranges obtained in Brazilian studies and those of other countries. Funari et al. ${ }^{8}$ and Carpes et al. ${ }^{9}$ found 5900-7200 $\mathrm{mg} \mathrm{kg}^{-1}$ and $3722-6364 \mathrm{mg} \mathrm{kg}^{-1} \mathrm{~K}$ in samples from SP and from PR, SC and RS, respectively. Samples from Spain, ${ }^{6}$ Australia, ${ }^{16}$ Poland, South Korea, China ${ }^{18}$ and Argentina ${ }^{17}$ presented the following K ranges: 2485-6411 $\mathrm{mg} \mathrm{kg}^{-1}, 2200-3800 \mathrm{mg} \mathrm{kg}^{-1}$, 2843-4854 mg kg-1 $3455-5489 \mathrm{mg} \mathrm{kg}^{-1}, 4247-5976 \mathrm{mg} \mathrm{kg}^{-1}$, 2263-9784 $\mathrm{mg} \mathrm{kg}^{-1}$, respectively.

Serra-Bonvehí, and Escolà-Jordà ${ }^{6}$ found in Spanish samples phosphorus values ten times lower (295-854 $\mathrm{mg} \mathrm{kg}^{-1}$ ) than those of the present study (2177-8165 mg kg-1). Our results corroborated the ranges found by Somerville and Nicol ${ }^{16}$ for Australian (1400-8000 mg kg-1) and Brazilian samples (3900-5000 mg kg-1 in samples from SP and 5648-8865 $\mathrm{mg} \mathrm{kg}^{-1}$ in samples from PR, SC and RS). ${ }^{8,9}$

Our pollen samples presented higher Ca levels (828-4670 $\mathrm{mg} \mathrm{kg}^{-1}$ ) than those found in Spanish (253-850 mg kg-1), ${ }^{4}$ South Korean (105-694 mg kg-1) and in some Chinese (181-974 $\mathrm{mg} \mathrm{kg}^{-1}$ ) and Polish (542-1080 $\mathrm{mg} \mathrm{kg}^{-1}$ ) samples. ${ }^{18}$ Our levels were closer to the ones found in Australian (360-3100 mg kg-1), ${ }^{16}$ Argentinian (160-2490 mg kg-1 ${ }^{17}$ and Brazilian (1500-3000 mg kg-1, 292-2149 $\mathrm{mg} \mathrm{kg}^{-1}$ ) samples. ${ }^{8,9}$

Magnesium levels found in present study (348-3621 mg kg-1) covered the levels found in most of the other studies with ranges of 742-1723 for Polish, 987-1762 for South Korean, 1126-1893 for Chinese, ${ }^{18} 401-2210$ for Argentinian, ${ }^{17} 600-1000$ and 463-1235 $\mathrm{mg} \mathrm{kg}^{-1}$ for Brazilian samples. ${ }^{89}$ Spanish and Australian samples showed some lower Mg levels, with ranges between: 273-816 and 220-2700 mg kg-1 ${ }^{6,16}$
Sodium levels in the present study $\left(<0.004-1466 \mathrm{mg} \mathrm{kg}^{-1}\right)$ tend to be lower than those of Spanish (614-2375 $\left.\mathrm{mg} \mathrm{kg}^{-1}\right){ }^{7}$ Polish (293-2191 $\mathrm{mg} \mathrm{kg}^{-1}$ ) and Chinese pollen (1072-2447 $\left.\mathrm{mg} \mathrm{kg}^{-1}\right),{ }^{18}$ but in agreement with those found in Brazilian (12-636 mg kg-1), ${ }^{9}$ Argentinian (46-554 $\left.\mathrm{mg} \mathrm{kg}^{-1}\right),{ }^{17}$ Australian (16-480 $\left.\mathrm{mg} \mathrm{kg}^{-1}\right)^{16}$ and South Korean (454-1113 $\left.\mathrm{mg} \mathrm{kg}^{-1}\right)$ samples. $^{18}$

Our $\mathrm{Fe}$ and $\mathrm{Cu}$ levels have wider ranges (11-552 and $\left.3.2-25.4 \mathrm{mg} \mathrm{kg}^{-1}\right)$, that cover the results obtained in other studies. Fe ranged from 11.1 to $80.3,{ }^{6} 14$ to $520,{ }^{16} 40.4$ to $136.1,74.3$ to $365.9,59.0$ to 182.3 and 23 to $229 \mathrm{mg} \mathrm{kg}^{-1}$ in samples from Spain, Australia, Poland, South Korea, China and Argentina, respectively. ${ }^{17,18}$ In Brazilian bee pollen samples from $\mathrm{SP}$ and $\mathrm{PR}, \mathrm{SC}$ and $\mathrm{RS}, \mathrm{Fe}$ levels ranged from 90.7 to 145.0 and 27.9 to $203.3 \mathrm{mg} \mathrm{kg}^{-1}$, respectively. ${ }^{8,9}$

Copper ranges of 4-16, 3-42, 5.6-23.9, 5.3-14.7, 3.2-10.0 and 6.0-20.0 mg kg-1 were obtained in samples from Spain, Australia, Poland, South Korea, China and Argentina, respectively. ${ }^{6,16-18}$ In Brazilian bee pollen samples from $\mathrm{SP}$ and $\mathrm{PR}, \mathrm{SC}$ and $\mathrm{RS}, \mathrm{Cu}$ ranges were 10.0-18.0 and 4.5-17.8 $\mathrm{mg} \mathrm{kg}^{-1}$, respectively. ${ }^{8,9}$

For Mn, our results $\left(12-211 \mathrm{mg} \mathrm{kg}^{-1}\right)$ tend to be lower than some levels found in some Chinese pollen samples (13.2-429.9 $\left.\mathrm{mg} \mathrm{kg}^{-1}\right),{ }^{18}$ but are mostly in accordance with other work that obtained the following results: 7.4-18.3 $\mathrm{mg} \mathrm{kg}^{-1}$ for Spanish samples, ${ }^{6} 5-110 \mathrm{mg} \mathrm{kg}^{-1}$ for Australian samples, ${ }^{16} 13.3-59.7$ and $25.6-99.4 \mathrm{mg} \mathrm{kg}^{-1}$ for Polish and South Korean samples, ${ }^{18}$ respectively and $14-57 \mathrm{mg} \mathrm{kg}{ }^{-1}$ for Argentinian samples. ${ }^{17}$ Brazilian samples from SP and PR, SC and RS presented ranges of 19.0-54.8 $\mathrm{mg} \mathrm{kg}^{-1}$ and 18.7-129.4 $\mathrm{mg} \mathrm{kg}^{-1}$, respectively. ${ }^{8,9}$

In the present work $\mathrm{Zn}$ levels ranged from 41.4-65.3 $\mathrm{mg} \mathrm{kg}^{-1}$, with only one sample with a lower level $\left(5.1 \mathrm{mg} \mathrm{kg}^{-1}\right)$. With the exception of this last sample, our results are within the ranges of most studies: $19-81 \mathrm{mg} \mathrm{kg}^{-1}$ for Spanish samples, ${ }^{6} 16-340 \mathrm{mg} \mathrm{kg}^{-1}$ for Australian samples, ${ }^{16}$ 25.6-53.6, 23.7-60.7 and 23.9-38.3 mg kg-1 for Polish, South Korean and Chinese samples, ${ }^{18}$ respectively, and $23-106 \mathrm{mg} \mathrm{kg}^{-1}$ for Argentinian samples. ${ }^{17}$ Brazilian samples from SP and PR, SC and RS had ranges of 48.0-118.0 and 36.1-82.1 $\mathrm{mg} \mathrm{kg}^{-1}$, respectively. ${ }^{8,9}$

\section{Seasonal and geographical effects}

Variations of mineral levels of samples from the same sites in SP (São José dos Campos), SC (Campos Novos), BA (Canavieiras) and SE (Neópolis) during the year are shown in Figure 1. SP and SC are located in Southeastern and Southern areas of the country, respectively, while BA and SE are located in Northeastern region. 

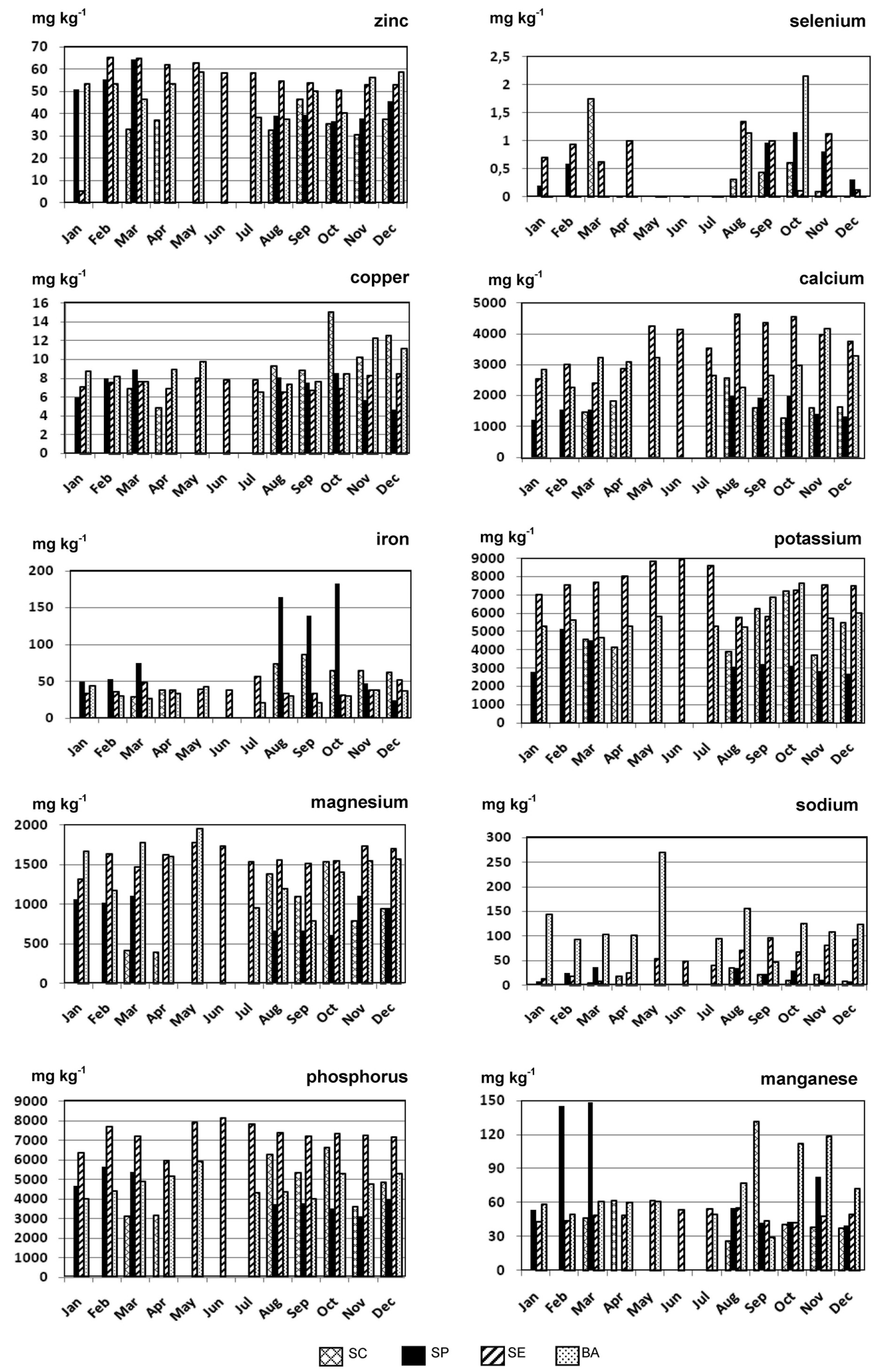

Figure 1. Variation of minerals levels of bee pollen during one year of production from the same sites of the following states: Santa Catarina (SC), São Paulo (SP), Sergipe (SE) and Bahia (BA). 
Pronounced variations are observed in the levels of all minerals during one year of bee pollen production. Although this variation presents a challenge to the appraisal of geographic effects, one can still observe that Brazilian pollen production is constant in Northeastern states (BA and SE), and the mineral levels tend to be higher, especially for $\mathrm{Zn}, \mathrm{Ca}, \mathrm{K}, \mathrm{Mg}$ and $\mathrm{P}$. In fact, apiculture has grown in this area of the country, which is considered to be prominent for beekeeping activity. The Northeastern region is one of the few in the world with the potential to produce organic bee products in large quantity, due to the great diversity of plant species and microclimates, along with vast unexplored land areas, free of conventional farming activity.

In SP and SC states bee pollen production is higher during the Spring season, which occurred from September 23 to December 12, decreasing during Summer (December 22 to March 19), Fall (March 20 to June 20), with low, if any production during the Winter season (June 21 to September 22). In addition, SP samples showed a tendency for higher Fe levels during August, September, and October and higher Mn levels during February and March.

The dendogram obtained by HCA is shown in Figure 2a. Cluster formed among bee pollen samples from the Southern and Southeastern states of SC, RS, PR and SP indicates that these samples are similar in mineral composition. Samples from DF and MT exhibit low similarity. Samples from MG and ES show similarity and samples from the Northeastern region (SE, PI, CE and BA) make up another group with similar composition.

The grouping of the samples through their similarities can be better explained by the PCA (Figure 2b) that indicates which mineral elements are responsible for the clusters. The samples of BA and SE can be characterized by the $\mathrm{Na}, \mathrm{Ca}$ and $\mathrm{Mg}$ contents. Those from PI and $\mathrm{CE}$ can be mainly defined by $\mathrm{Zn}, \mathrm{K}, \mathrm{Mn}$ and P. Cu influenced the samples from the Federal District while those of MG, RS, SP and MT are characterized by the Fe level.

\section{Estimated micronutrient contribution of pollen to the diet}

Contribution of the mineral elements in bee pollen to recommended daily intakes (RDI) established by Brazilian regulation per portion is shown in Table $4 .{ }^{30}$ In terms of the mean values, high contribution could come from Mn (69.6\% of RDI) and Se (37.5\% of RDI). According to Brazilian regulation, ${ }^{31}$ a contribution of more than $30 \%$ classifies the food as a rich source and above $15 \%$ as a source. In addition, Brazilian bee pollen may be a source of $\mathrm{Cu}(26.7 \%$ of RDI), P (17.2\% of RDI) and $\mathrm{Zn}(16.7 \%$ of RDI). It is notice worthy that $\mathrm{Cu}$ content did not vary
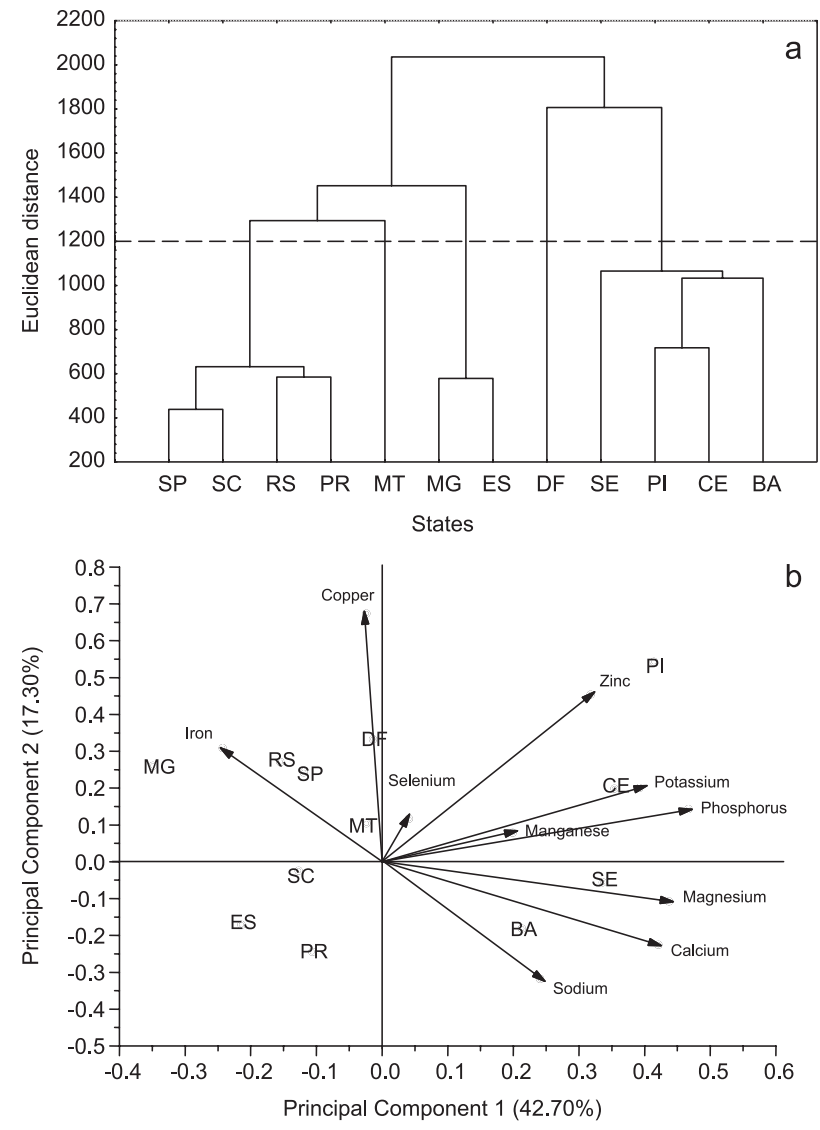

Figure 2. Dendogram (a) and principal components 1 and 2 (b) obtained from mean composition of mineral elements in 154 dehydrated bee pollen samples from 11 Brazilian states and the Federal District. Southern states: Rio Grande do Sul (RS), Santa Catarina (SC) and Paraná (PR). Southeastern states: São Paulo (SP), Minas Gerais (MG), Espírito Santo (ES). Midwestern state: Mato Grosso (MT). Northeastern states: Bahia (BA), Ceará (CE), Piauí (PI), Sergipe (SE). Central region: Federal District (DF).

Table 4. Percentage contribution of the mineral elements to Brazilian recommended daily intakes (RDI) for adults in relation to the mean levels found in the 154 Brazilian bee pollen samples

\begin{tabular}{lccc}
\hline Element & Mean content $/\left(\mathrm{mg} \mathrm{kg}^{-1}\right)$ & $\mathrm{RDI}^{\mathrm{a}} / \mathrm{mg}$ & $\mathrm{RDI}^{\mathrm{b}} / \%$ \\
\hline Sodium & 85 & 2400 & 0.1 \\
Calcium & 2215 & 1000 & 5.5 \\
Iron & 82 & 14 & 14.6 \\
Magnesium & 1179 & 260 & 11.3 \\
Zinc & 46.7 & 7 & 16.7 \\
Phosphorus & 4828 & 700 & 17.2 \\
Copper & 9.6 & 0.9 & 26.7 \\
Selenium & 0.51 & 0.034 & 37.5 \\
Potassium & 5089 & $4700^{*}$ & 2.7 \\
Manganese & 64 & 2.3 & 69.6 \\
\hline
\end{tabular}

${ }^{\mathrm{a} B r a z i l i a n}$ Ministry of Health. ${ }^{24}$ bConsidering a 25 g portion. ${ }^{29} *$ Dietary Reference Intakes (DRI), according to Institute of Medicine, ${ }^{28}$ not established by Brazilian regulation. 
among the studied localities. The high $\mathrm{K} / \mathrm{Na}$ ratio makes bee pollen potentially valuable for diets with defined electrolytic balance.

Selenium, $\mathrm{Cu}$ and $\mathrm{Zn}$ are considered antioxidant nutrients, since they are structural components of the antioxidant enzymes: $\mathrm{Cu}$ and $\mathrm{Zn}$ in superoxide dismutase (SOD) and $\mathrm{Se}$ in plasmatic glutathione peroxidase (GSHPx), respectively. Zn can also inactivate superoxide radicals in cytosol and mitochondria. ${ }^{32,33}$ The presence of these three elements in Brazilian bee pollen, together with expressive amounts of flavonoids and others components points to this product as a potential source of antioxidants in the human diet. ${ }^{34-36}$

\section{Conclusions}

The method used to determine the mineral elements, which consisted of microwave-assisted digestion in closed system and quantification by inductively coupled plasma optical emission spectrometry (ICP OES) showed good precision and accuracy, additionally allowing simultaneous determination of micro and macroelements in bee pollen samples. Wide within-state and between-state variations exist in the mineral composition of dehydrated bee polen. $\mathrm{K}, \mathrm{P}, \mathrm{Ca}$ and $\mathrm{Mg}$ are the major mineral elements present in the pollen composition. Northeastern Brazilian states seem to be promising for bee pollen production, since samples from this region presented significantly higher amounts of minerals and showed constant production throughout the year. In terms of mean values, Brazilian bee pollen may be considered a rich source of $\mathrm{Mn}$ and Se and a source of $\mathrm{Cu}, \mathrm{P}$ and $\mathrm{Zn}$. The high $\mathrm{K} / \mathrm{Na}$ ratio can make it a valuable product for diets with defined electrolytic balance; and the presence of $\mathrm{Se}, \mathrm{Cu}$ and $\mathrm{Zn}$ makes it a potential source of antioxidant minerals to the human diet.

\section{Acknowledgments}

The authors are grateful for financial support from the Brazilian government agencies Fundação de Amparo à Pesquisa do Estado de São Paulo (FAPESP), Conselho Nacional de Desenvolvimento Científico e Tecnológico (CNPq) and Centro Universitário Adventista de São Paulo (UNASP).

\section{References}

1. Resende, R.; Exportações de Mel Crescem $54 \%$ em Dezembro de 2010; http://www.sebrae.com.br/setor/apicultura/ sobre-apicultura/mercado/exportacoes/integra_bia?ident_ unico $=15801$ accessed in October 2011.
2. SEBRAE - Serviço Brasileiro de Apoio às Micro e Pequenas Empresas; Informações de Mercado Sobre Mel e Outros Derivados das Abelhas: Sumário Executivo, Série Mercado, 2007; http://www.biblioteca.sebrae.com.br/bds/BDS.nsf/E41 C0BA5033EB42D8325727D004FCE50/\$File/NT00035056. pdf accessed in October 2011.

3. Loper, G. M.; Standifer, L. N.; Thompson, M. J.; Gilliam, M.; Apidologie 1980, 11, 63.

4. Bonvehí, J. S.; Galindo, J. G.; Pajuelo, A. G.; Alimentaria 1986, 176, 63.

5. Jeanne, F.; Bull. Tech. Apic. 1993, 20, 23.

6. Serra-Bonvehí, J.; Escolà-Jordà, R.; J. Agric. Food. Chem. 1997, 45,725 .

7. Carpes, S. T.; Begnini, R.; Alencar, S. M.; Masson, M. L.; Ciênc. Agrotec. 2007, 31, 1818.

8. Funari, S. R. C.; Rocha, H. C.; Sforcin, J. M.; Filho, H. G.; Curi, P. R.; Dierckx, S. M. A. G.; Funari, A. R. M.; Orsi, R. O.; Arch. Latinoam. Produccion Animal 2003, 11, 88.

9. Carpes, S. T.; Mourão, G. B.; de Alencar, S. M.; Braz. J. Food Technol. 2009, 12, 220.

10. Herbert Jr., E. W.; Shimanuky, H.; Apidologie 1978, 9, 33.

11. O’Rourke, M. K.; Buchmann, S. L.; Environ. Entomol. 1991, 20, 507.

12. Almeida-Muradian, L. B.; Pamplona, L. C.; Coimbra, S.; Barth, O. M..; J. Food Comp. Anal. 2005, 18, 105.

13. Pereira, F. M.; Freitas, B. M.; Vieira-Neto, J. M.; Lopes, M. T. R.; Barbosa, A. L.; Camargo, R. C. R..; Pesqui. Agropecu. Bras. 2006, 41,1 .

14. Day, S.; Beyer, R.; Mercer, A.; Ogden, S.; J. Apic. Res. 1990, 29, 138.

15. Kump, P.; Necemer, M.; Snajder, J.; Spectrochim. Acta, Part B 1996, 51, 499.

16. Somerville, D. C.; Nicol, H. I.; Aust. J. Exp. Agr. 2002, 42, 1131.

17. Baldi-Coronel, B.; Grasso, D.; Pereira, S. C.; Fernández, G.; Cienc. Docencia Tecnol. 2004, 29, 145.

18. Szczesna, T.; J. Apic. Sci. 2007, 51, 5.

19. Abreu, M.; Alimentaria 1992, 235, 45.

20. Conti, M. H.; Botrè, F.; Environ. Monit. Assess. 2001, 69, 267.

21. Saavedra, A. R.; Di Bernardo, M. L.; Rondon, C.; Gutiérrez, L.; Saavedra, O.; González, I.; Vit, P.; Rev. Inst. Nac. Hig. 2007, 38,6 .

22. Morgano, M.A.; Martins, M. C. T.; Rabonato, L. C.; Milani, R. F.; Yotsuyanagi, K.; Rodriguez-Amaya, D. B.; J. Agric. Food Chem. 2010, 58, 6876.

23. Mermet, J. M.; Poussel, E.; Appl. Spectrosc. 1995, 49, 12.

24. Brazilian Ministry of Health, Agência Nacional de Vigilância Sanitária (ANVISA); Resolução RDC N. 269, 22 de Setembro de 2005: Regulamento Técnico Sobre a Ingestão Diária Recomendada (IDR) de Proteína, Vitaminas e Minerais; Brasília, DF, Brasil, 2005. 
25. FAO/WHO; Human Vitamin and Mineral Requirements; Report of a Joint FAO/WHO Expert Consultation, Bangkok, Thailand; http://ftp://ftp.fao.org/docrep/fao/004/y2809e/y2809e00.pdf accessed in January 2011.

26. IOM, Institute of Medicine; Dietary Reference Intakes: Applications in Dietary Assessment; National Academy Press: Washington, DC, 2000; http://www.nap.edu accessed in June 2011.

27. IOM, Institute of Medicine; Dietary Reference Intakes for Vitamin A, Vitamin K, Arsenic, Boron, Chromium, Cooper, Iodine, Iron, Manganese, Molybdenum, Nickel, Silicon, Vanadium, and Zinc; National Academy Press: Washington, DC; http://www.nap.edu accessed in June 2011.

28. IOM, Institute of Medicine; Dietary Reference Intakes for Water, Potassium, Sodium, Chloride, and Sulfate; National Academy Press: Washington, DC, 2004; http://www.nap.edu accessed in June 2011.

29. Lengler, S.; Pólen Apícola, Centro de Ciências Rurais, Universidade Federal de Santa Maria, 2a. ed., 2002; http://www. brasilapicola.com.br/files/apostila_polen_apicola.pdf accessed in June 2011.
30. ANVISA - Agência Nacional de Vigilância Sanitária; Brazilian Ministry of Health; Resolução RDC N. 269, 22 de Setembro de 2005: Regulamento Técnico sobre a Ingestão Diária Recomendada (IDR) de Proteína, Vitaminas e Minerais, Brasília, DF, Brasil, 2005.

31. ANVISA - Agência Nacional de Vigilância Sanitária; Brazilian Ministry of Health; Portaria N. 27, 13 de Janeiro de 1998: Informação Nutricional Complementar, Brasília, DF, Brasil, 1998.

32. Rauma, A. L.; Mykkanen, H.; Nutrition 2000, 16, 111.

33. Moraes, M. L.; Feijó, M. B. S.; Melo, F. M.; Campos, R.C.; Hauser-Davis, R.A.; J. Braz. Chem. Soc. 2009, 20, 1724.

34. Martins, M. C. T.; Rodrigues-Amaya, D.; Morgano, M. A.; Rodrigues, M. I.; Rev. Inst. Adolfo Lutz 2011, 70, 122.

35. Martins, M. C.; Morgano, M. A.; Vicente, E.; Baggio, S. R.; Rodriguez-Amaya, D.; J. Apic. Sci. 2011, 55, 73.

36. Morgano, M. A.; Milani, R. F.; Martins, M. C.; RodriguezAmaya, D. B.; Food Control 2011, 22, 1604.

Submitted: November 21, 2011

Published online: March 8, 2012

FAPESP has sponsored the publication of this article. 